\title{
Deskrpisi Keberhasilan Terapi SEFT pada Penderita Hipertensi Di Desa Pandau Jaya Kec. Siak Hulu Kab. Kampar
}

\author{
Maswarni $^{1}$, Hayana $^{2}$ \\ Email : maswarni@umri.ac.id, hayana.yana1986@gmail.com \\ ${ }^{1}$ Program Studi keperawatan, Fakultas Matematika Ilmu Pengetahuan Alam dan Kesehatan, \\ Universitas Muhammadiyah Riau \\ ${ }^{2}$ Program Studi Ilmu Kesehatan Masyarakat, Sekolah Tinggi Ilmu Kesehatan Hang tuah \\ Pekanbaru
}

\section{ABSTRAK}

Terapi SEFT dapat digunakan sebagai salah satu tehnik terapi untuk mengatasi masalah emosional dan fisik, yaitu dengan melakukan totok ringan (tapping) pada titik syaraf (meridian tubuh). Spiritual dalam SEFT adalah doa yang diafirmasikan oleh klien pada saat akan dimulai hingga sesi terapi berakhir. Terapi SEFT bersifat universal, artinya untuk semua kalangan tanpa membeda-bedakan latar belakang keyakinan klien. Hipertensi merupakan penyakit yang tidak dapat disembuhkan sehingga memerlukan penanganan yang rumit dan sulit. Penyakit hipertensi juga menyebabkan komplikasi yang serius apabila tidak mendapatkan penanganan yang serius.Tujuan dalam penelitian ini adalah untuk melihat gamabaran keberhasilan terapi Spiritual Emotional Freedom Technique (SEFT) terhadap penurunan tekanan darah pada penderita hipetensi di Desa Pandau Jaya. Penelitian ini menggunakan desain quasieksperimental pre dan post control group design dan berjumlah 64 responden dibagi menjadi dua kelompok,kelompok intervensi 32 responden dan kelompok kontrol 32 responden. Instrumen penelitian teridiri dari tensimeter air raksa, manset ukuran dewasa dan stetoskop. Teknik pengambilan sampel menggunakan purposive sampling. Pada penelitian ini digunakan ujistatistik Uji $t$ dependent(paired-sample $t$ test) untuk untuk melihat gambaran perubahan tekanan darah sistole dan diastole pada penderita hipertensi di kelompok kontrol dan kelompok intervensi kontrol . Hasil Penelitian terdapat perubahan tekanan pada kelompok kontrol sistole $157 \mathrm{mmHg}$ diastole $96 \mathrm{mmHg}$ dan Kelompok Intervensi sistole $146 \mathrm{mmHg}$ dan diastole $87,35 \mathrm{mmHg}$. Berdasarkan hasil penelitian terdapat perubahan tekanan darah sebelum dan sesudah di lakukan terapi SEFT, di saran untuk menggunakan terapi SEFT sebagai pengobatan alternatif untuk hipertensi

Kata kunci : Hipertensi, Terapi, SEFT 


\section{PENDAHULUAN}

Hipertensi adalah penyebab kematian karena stroke dan faktor yang memperberat infark miokard (serangan jantung). Kondisi tersebut merupakan gangguan yang paling umum pada tekanan darah, hipertensi merupakan gangguan asimptomatik yang sering terjadi ditandai dengan peningkatan tekanan darah secara persisten). Hipertensi dapat didefinisikan sebagai tekanan darah persisten dimana tekanan sistoliknya di atas $140 \mathrm{mmHg}$ dan tekanan diastoliknya $90 \mathrm{mmHg}^{2}$.

Definisi Hipertensi atau tekanan darah tinggi adalah peningkatan tekanan darah sistolik lebih dari $140 \mathrm{mmHg}$ dan tekanan darah diastolik lebih dari $90 \mathrm{mmHg}$ pada dua kali pengukuran dengan selang waktu lima menit dalam keadaan cukup istirahat/tenang. Peningkatan tekanan darah yang berlangsung dalam jangka waktu lama (persisten) dapat menimbulkan kerusakan pada ginjal (gagal ginjal), jantung (penyakit jantung koroner) dan otak (menyebabkan stroke) bila tidak dideteksi secara dini dan mendapat pengobatan yang memadai. Banyak pasien hipertensi dengan tekanan darah tidak terkontrol dan jumlahnya terus meningkat.

Hipertensi dapat berakibat fatal jika tidak dikontrol dengan baik atau biasa disebut dengan komplikasi. Komplikasi hipertensi terjadi karena kerusakan organ yang diakibatkan peningkatan tekanan darah sangat tinggi dalam waktu lama. Tingginya tekanan darah yang lama tentu saja akan merusak pembuluh darah di seluruh tubuh, yang paling jelas pada mata, jantung, ginjal dan otak. Maka konsekuensi yang biasa pada hipertensi yang lama tidak terkontrol adalah gangguan penglihatan, oklusi koroner, gagal ginjal, dan stroke. Selain itu jantung membesar karena dipaksa meningkatkan beban kerja karena saat memompa melawan tingginya tekanan.

Lipsky, at al. (2008) menyatakan bahwa tekanan darah tinggi dapat diturunkan melalui perubahan gaya hidup diantaranya manajemen stres dimana stres dapat meningkatkan tekanan darah. Salah satu caranya adalah dengan teknik relaksasi. Relaksasi merupakan salah satu teknik pengolahan diri yang didasarkan pada cara kerja sistem saraf simpatis dan parasimpatis. Relaksasi ini mampu menghambat stres atau ketegangan jiwa yang dialami seseorang sehingga tekanan darah tidak meninggi ${ }^{5}$

Salah satu penyakit tidak menular yang menjadi masalah kesehatan yang sangat serius saat ini adalah hipertensi. Hipertensi dapat didefinisikan sebagai tekanan darah persisten dimana tekanan sistoliknya di atas $140 \mathrm{mmHg}$ dan tekanan diastolik di atas $90 \mathrm{mmHg}$. Pada populasi lansia, hipertensi didefinisikan sebagai tekanan sistolik $\geq 160 \mathrm{mmHg}$ dan tekanan diastolik $\geq 90 \mathrm{mmHg}$. Hipertensi disebut sebagai the silent killer atau "pembunuh diam- diam" karena orang dengan hipertensi sering tidak menampakkan gejala dan tidak sadar akan kondisinya. Hipertensi merupakan penyebab utama penyakit gagal jantung, stroke dan gagal ginjal (Smeltzer, 2004).

Hipertensi menjadi masalah kesehatan di seluruh dunia karena prevalensinya yang tinggi. Data WHO tahun 2000, hipertensi telah menjangkiti $26,4 \%$ populasi dunia dengan perbandingan $26,6 \%$ pada pria dan $26,1 \%$ pada wanita. Pengaruh terapi, Sebanyak $26,6 \%$ populasi dunia, negara berkembang menyumbang $2 / 3$ populasi yang terjangkit hipertensi, sedangkan negara maju hanya menyumbang sepertiganya saja. Data yang dilansir oleh The Lancet tahun 2000 sebanyak 972 juta (26\%) orang dewasa di dunia menderita Hipertensi. Angka ini terus meningkat tajam, diprediksikan oleh WHO pada tahun 2025 nanti sekitar 29\% orang dewasa di seluruh dunia yang menderita hipertensi (Rahajeng \& Tuminah, 2009) 
Prevalensi terhadap penyakit tidak menular di Indonesia mengalami peningkatan. Kecendrungan meningkatnya prevalensi penyakit tidak menular salah satunya adalah hipertensi yang disebut sebagai the silent killer . Jumlah penderita hipertensi di dunia mengalami peningkatan setiap tahun. Menurut survei yang dilakukan oleh organisasi kesehatan dunia (WHO) tahun 2011 menyebutkan bahwa di seluruh dunia sekitar 972.000 .000 orang atau $26,4 \%$ penduduk dunia mengidap penyakit tersebut dengan perbandingan $26,6 \%$ pria dan $26,1 \%$ wanita. Angka ini kemungkinan akan meningkat menjadi 29,2 \% ditahun 2025. Jumlah penderita di negara maju berkisar 333.000 .000 jiwa dan 639.000.000 jiwa di negara berkembang. Hipertensi juga membunuh hampir 8.000.000 orang setiap tahun dimana hampir 1,5 juta adalah penduduk Asia Tenggara ${ }^{6}$

Hasil Riset Kesehatan Dasar tahun 2013 prevalensi hipertensi di Indonesia berdasarkan hasil pengukuran pada umur $\geq 18$ tahun sebesar 25,8 persen dan $63,2 \%$ kasus hipertensi di masyarakat tidak terdiagnosis. Angka kejadian hipertensi menjadi penyebab kematian sebesar 6,8\%. Banyak faktor yang dapat menyebabkan terjadinya hipertensi, seperti kurangnya sarana dan prasaranan dalam penanggulangan hipertensi ${ }^{7}$.

Tingginya angka hipertensi dipengaruhi oleh kebiasaan merokok, kurangnya aktifitas, pola makan yang tidak sehat, obesitas dan stres. Peningkatan jumlah penderita hipertensi juga ditemukan di Pekanbaru Provinsi Riau. Berdasarkan data Dinas Kesehatan Kota Pekanbaru tahun 2014, pada tahun 2012 jumlah penderita tersebut sebanyak 19.878 orang, meningkat menjadi 24.509 orang padatahun 2013, dan kembali turun pada tahun 2014 menjadi 20.601 orang.

Penderita hipertensi sering merasa takut dan cemas menghadapi penyakit yang dideritanya, takut akan ancaman komplikasi, takut tekanan darahnya serin tinggi, bahkan takut tidak sembuh lagi ${ }^{8}$. Penderita hipertensi juga umumnya memiliki emosi yang labil sehingga mudah marah dalam menghadapi masalah yang menimbulkan tekanan darah menjadi tinggi.

Penanganan hipertensi menurut Gunawan (2001), secara garis besar dibagi menjadi 2 jenis yaitu secara farmakologis dan non farmakologis. Terapi farmakologis yang selama ini digunakan adalah obat antihipertensi. Terapi farmakologis dapat dikombinasikan dengan terapi non farmakologis yang banyak macamnya, mulai dari pengaturan pola hidup, berbagai terapi komplementer sampai intervensi spiritual yang sekarang ini banyak dikembangkan. Sehingga penatalaksanaan hipertensi bukan saja pada aspek biologis, tetapi juga aspek psikis dan spiritual.

Terapi spiritual emotional freedom technique (SEFT) termasuk tehnik relaksasi, merupakan salah satu bentuk mind-body therapy dari terapi komplementer dan alternative keperawatan SEFT merupakan teknik penggabungan dari sistem energy tubuh (energy medicine) dan terapi spiritual dengan menggunakan tapping pada titik- titik tertentu pada tubuh. Terapi SEFT bekerja dengan prinsip yang kurang lebih sama dengan akupuntur dan akupresur. etiganya berusaha meerangsang titik- titik kunci pada sepanjang 12 jalur energy (energy meridian) tubuh. Bedanya dibandingkan denga metode akupuntur dan akupresur adalah teknik SEFT menggunakan unsur spiritual, cara yang digunakan lebih aman, lebih mudah, lebih cepat dan lebih sederhana, karena SEFT hanya menggunakan ketukan tingan (tapping).

\section{METODE PENELITIAN}

Penelitian ini menggunakan desain quasi-eksperimental. Rancangan yang digunakan adalah quasi eksperimen pre dan post control group design. Rancangan ini digunakan untuk membandingkan hasil intervensi dimana desain ini dibagi menjadi dua kelompok yaitu kelompok kontrol dan kelompok intervensi yang keduanya diukur sebelum dan sesudah diberikan terapi spiritual 
emotional freedom technique (SEFT) dengan pengambilan sampel tidak dilakukan secara acak . Instrumen Pada penelitiaan ini yang akan digunakan untuk pengumpulan data berupa lembar observasi pelaksanaan terapi SEFT, kuesioner karakteristik responden dan alat ukur tekanan darah (tensimeter air raksa, manset ukuran dewasa dan stetoskop). Teknik pengambilan sampel menggunakan purposive sampling. Pada penelitian menggunakan ujistatistik Uji $t$ dependent(paired-sample $t$ test) untuk melihat deskripsi perubahan tekanan dara sistole dan diastole pada penderita hipertensi di kelompok intervensi dan kelompok kontrol .

\section{HASIL DAN PEMBAHASAN}

1. Karakteristik Penderita Tekanan Darah di RW 024 Desa Pandau Jaya

Tabel 1 Karakteristik Penderita Hipertensi di RW 024 Desa Pandau Jaya

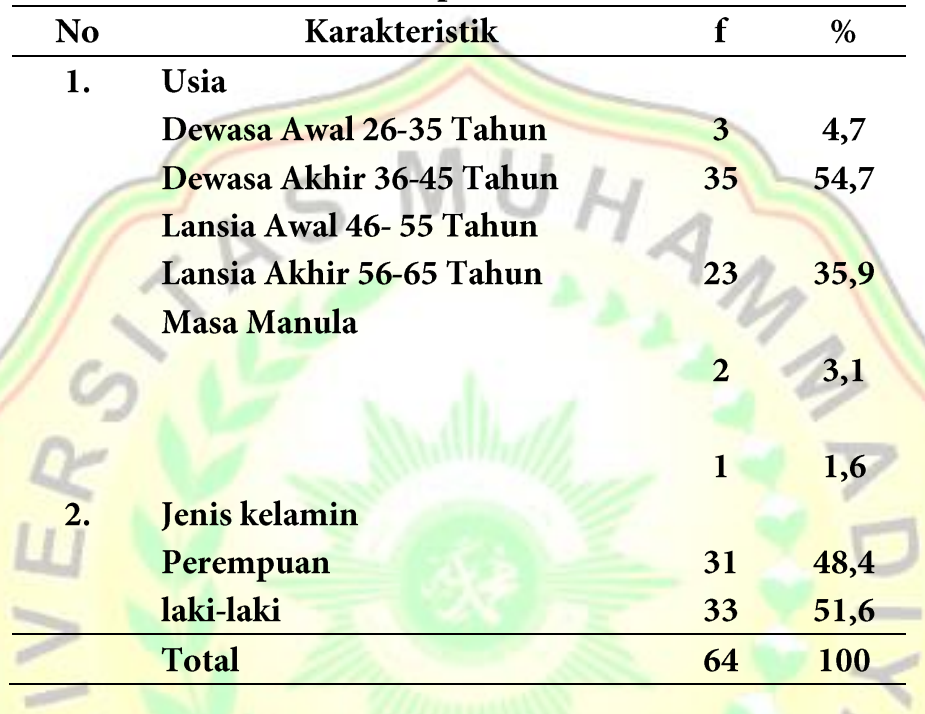

Berdasarkan tabel 1 di dapati bahwa responden yang paling banyak adalah dewasa Akhir 36-45 tahun dengan jumlah sebanyak 35 orang responden $(54,7 \%)$ sedangkan reponden yang paling sedikit adalah Masa Manula dengan jumlah sebanyak 1 orang responden (1,6\%). Selanjutnya untuk jenis kelamin yang paling banyak adalah perempuan sebanyak 31 orang responden $(48,4 \%)$

2. Rerata Tekanan Darah ( $\mathrm{mmHg}$ ) sebelum di berikan Terapi SEFT pada kelompok Intervensi Dan Kontrol

Tabel 2 Tekanan Darah (mmHg) sebelum di berikan Terapi SEFT pada kelompok Intervensi

\section{Dan Kontrol}

\begin{tabular}{lcclc}
\hline Kelompok & Variabel & n & Rerata & SD \\
\hline Intervensi & TD Sistole & 32 & 158,25 & 6,53 \\
& TD Diastole & 32 & 98,18 & 4,61 \\
\multirow{3}{*}{ Kontrol } & TD Sistole & 32 & 157,81 & 4,15 \\
& TD Diastole & 32 & 95,31 & 6,86 \\
\hline
\end{tabular}


Berdasarkan tabel 2 dapat diketahui bahwa pada kelompok intervensi sebelum diberikan terapi spiritual emotional freedom technique (SEFT)rata rata TD sistole 158, $25 \mathrm{mmHg}$ dengan standar deviasi 6,53 mmHg sedangkan rata rata TD diastole $98,18 \mathrm{mmHg}$ dengan standar deviasi 4,61 mmHg. Adapun pada kelompok kontrol sebelum diberikan perlakuan rata rata TD sistole adalah 157, $81 \mathrm{mmHg}$ dengan standar deviasi 4,15 mmHg sedangkan rata-rata TD diastol yaitu sebesar 95, $31 \mathrm{mmHg}$ dengan standar deviasi $6,86 \mathrm{mmHg}$

3. Rerata Tekanan Darah sesudah di berikan Terapi SEFT pada kelompok Intervensi Dan Kontrol

Tabel 3 Tekanan Darah sebelum di berikan Terapi SEFT pada kelompok Intervensi Dan Kontrol

\begin{tabular}{cccccc}
\hline Kelompok & Variabel & n & Rerata & SD \\
\hline Intervensi & TD Sistole & 32 & 146 & 7,25 \\
& TD Diastole & 32 & 87,35 & 3,92 \\
\multirow{4}{*}{ Kontrol } & TD Sistole & 32 & 157,81 & 4,90 \\
& TD Diastole & 32 & 96,25 & 5,37 \\
\hline & & & & \\
\hline & & & &
\end{tabular}

Pada tabel 3 di atas dapat dilihat bahwa pada kelompok intervensi sesudah dilakukan terapi SEFT dengan nilai rata rata sistole 146, $12 \mathrm{mmHg}$ dengan standar deviasi 7,25 $\mathrm{mmHg}$, dan untuk nilai rata rata pada diastolnya yaitu $87,35 \mathrm{mmHg}$ dengan standar deviasinya $3,92 \mathrm{mmHg}$. Semntara itu pada kelompok kontrol sesudah perlakuan di dapati nilai rata-rata sistole 157, $81 \mathrm{mmHg}$ dengan standar deviasi 4, $90 \mathrm{mmHg}$ selanjutnya nilai rata-rata diastole yaitu $96,25 \mathrm{mmHg}$ dengan standar deviasi 5, $37 \mathrm{mmHg}$.

Dilihat rata-rata tekanan darah pada kelompok intervensi dan kelompok kontrol setelah diberikan suatu perlakuan, responden hipertensi kelompok intervensi yang diberikan terapi spiritual emotional freedom technique (SEFT) mengalami perubahan penurunan tekanan darah sedangkan pada kelompok kontrol atau kelompok yang diberikan perlakuan mengalami penurunan tekanan darah yang tidak bermakna. Hal ini menunjukkan bahwa ada pengaruh terapi SEFT terhadap penurunan tekanan darah.

Pada Penelitian Zulaichah (2013) yang berjudul "Pengaruh Terapi SEFT Terhadap Penurunan Tekanan Darah Pada Lansia Hipertensi di Puskesmas Jagir Surabaya”. Hasil penelitian yang telah dilakukan pada 15 responden yang dibagi dalam dua kelompok eksperimen dan kelompok kontrol menunjukkan ada pengaruh terapi SEFT terhadap tekanan darah penderita hipertensi di Puskesmas Jagir Surabaya, dengan $p$ value $0,000<\alpha 0.05$.

Senada juga dengan Nurfaridah (2012) yang berjudul "Pengaruh Terapi SEFT Islami Terhadap Tekanan Darah Pada Penderita Hipertensi Usia 45-59 Tahun di RSUD Dr. Soegiri Lamogan”. Hasil penelitian yang telah dilakukan pada 30 responden yang dibagi dalam dua kelompok eksperimen dan kelompok kontrol menunjukkan ada pengaruh terapi SEFT terhadap tekanan darah penderita hipertensi di RSUD Dr. Soegiri Lamogan, dengan $p$ value $0,000<\alpha 0,05 .{ }^{11}$

Menurut Teti(2013) dalam peneltian yang berjudul : Pengaruh Terapi SEFT ( Spritual Emotional Freedom Technique ) terhadap Penurunan Tekanan Darah Pada Penderita Hipertensi Di Wilayah Puskesmas Tahunan menunjukkan adanya penurunan tekanan diastolik sesudah dilakukan terapi SEFT. 
Menurut Thayib (2010) jika menstimulasi titik-titik meridian tubuh selama 10-15 menit dan dengan intensitas ketukan yang sama dapat membantu mengurangi kecemasan dan membuat perasaan menjadi lebih tenang dan nyaman, dengan menstimulasi titik- titik SEFT dapat menstimulus pengeluaran hormon endorfin yang berfungsi sebagai hormon kebahagiaan.

Menurut Lane, (2009) yang menunjukkan bahwa menstimulasi secara manual pada titik akupuntur dapat mengontrol kortisol. Hal ini sesuai dengan penelitian Dawson, Garrret \& audrey (2012) dalam the Journal of Nervous and Mental Disease yang mencoba menggunakan EFT dalam menurunkan kortisol pada stress, berdasarkan hasil penelitian tersebut EFT mampu menurunkan kadar kortisol sebesar -24.39 \%. Dengan menurunnya kadar kortisol. Terapi Spiritual Emotional Freedom Technique (SEFT) menggunakan teknik yang aman, mudah, cepat, dan sederhana, bahkan tanpa risiko, karena tidak menggunakan alat atau jarum. Hanya dengan jari telunjuk dan jari tengah kita yang di ketuk ketukkan ringan di beberapa titik meridian tubuh. Selain itu, dengan melibatkan Tuhan dalam proses energi psikologi ini menjadikan SEFT mengalami amplfying effect sehingga spektrum masalah yang dapat diatasi juga jauh lebih luas meliputi fisik dan emosi, kesuksesan diri, kebahagiaan hati dan menjadikan jalan menuju personal greatness (kemuliaan diri).

Hasil penelitian ini didukung penelitian Sunardi dkk. (2014), yang melakukan penelitian tentang efektifitas terapi SEFT dalam menurunkan hipertensi di dusun Nusantoro desa Ampeldento. Hasil penelitian menunjukkan bahwa hasil uji t-test Independent pada tekanan darah sistolik didapatkan nilai p-value 0,023 $(\mathrm{P}<0,05)$, sehingga dapat disimpulkan bahwa $\mathrm{HO}$ ditolak berarti ada perbedaan. Sedangkan pada tekanan darah diastolik didapatkan nilai p-value 0,836 $(\mathrm{P}>0,05)$, maka dapat disimpulkan bahwa $\mathrm{HO}$ diterima. Sehingga dapat disimpulkan bahwa tidak terdapat perbedaan tekanan darah diastol antara kelompok intervensi dan kelompok kontrol pada tekanan darah diastol.

Dengan melakukan terapi Spiritual Emotional Freedom Technique (SEFT), masalah emosi maupun masalah fisik yang dialami oleh seseorang misalnya dismenorea maka tingkat nyeri yang dirasakan akan berkurang, bahkan akan hilang dalam waktu yang singkat. Hal ini dikarenakan Spiritual Emotional Freedom Technique (SEFT) lebih menekankan pada unsur spiritualitas (doa) dan sistem energi tubuh dengan menggunakan metode tapping pada beberapa titik tertentu pada tubuh. Selain sistem energi tubuh terdapat pula metode relaksasi dengan melibatkan faktor keyakinan pasien yang diyakini dapat menurukan tekanan darah.

\section{KESIMPULAN DAN SARAN}

Terapi SEFT merupakan salah satu terapi modalitas yang efektif menurunkan tekanan darah pada penderita hipertensi. Terapi SEFT ini bisa di pelajari oleh siaapun juga kemudian mensosialisasikannya kepada masyarakat luas Terapi SEFT dapat dilakukan kapan saja dan oleh siapa saja. Dalam kajian yang luas terapi SEFT sering digunakan pada penyakit mental seperti stres dan depresi, mereka juga dijangkiti penyakit fisik yang cukup berat seperti, alergi, maag, migrain, dll. Tentu saja terapi SEFT ini bisa dikembangkan lagi lebih lanjut.

\section{Daftar Pustaka}

1. Tarigan, A. R., Lubis2, Z. \& Syarifah. Pengaruh pengetahuan, sikap dan dukungan kelaurga terhadap diet hipertensi di Desa Hulu Kecamatan Pancur Batu Tahun 2016. J. Kesehat. 11, 9-17 (2018).

2. Kowalski E Robert. Terapi Hipetensi : Program 8 minggu menurunkan tekanan darah tinggi dan mengurangi resiko serangan jantung dan stroke alami. (2010). 
3. Kemenkes.RI. Pusdatin STROKE. Pusat Data Dan Informasi Kementrian Kesehatan (2014). doi:10.1177/109019817400200403

4. Smeltzer. S. C., \& Bare, B. G. Buku Ajar Keperawatan Medikal-Bedah Brunner \& Suddart Ed 8 Vol 2. Jakarta: EGC. (2002).

5. Lipsky, Martin S., at. A. American medical association guide preventing and treating heart disease: essential information you and your family neet to know about having a healthy heart. United States of America: American Medical Association. (2008).

6. Murni. EFEKTIVITAS TERAPI SPRITUAL EMOTIONAL FREEDOM TECHNIQUE (SEFT ) TERHADAP PENURUNAN TEKANAN DARAH. photon 8, 151-158 (2018).

7. Julianty, P. Faktor-faktor yang mempengaruhi terjadinya hipertensi di daerah perkotaan. Gizi Indones. 33, 59-66 (2010).

8. Noerhadi, dr M. Hipertensi Dan Pengaruhnya Terhadap Organ-Organ Tubuh. Medikora 4, 1-18 (2008).

9. Deby, S. Technique (Seft) Terhadap Penurunan Tekanan Darah Pada Penderita Hipertensi Di Wilayah Kerja Puskesmas Pauh Kota Padang. Fak. Keperawatan (2015).

10. Rofacky, H. F. dan F. A. Pengaruh Terapi Spiritual Emotional Freedom Technique (SEFT) Terhadap Tekanan Darah Penderita Hipertensi. J. Keperawatan Soedirman (The Soedirman J. Nursing) 2, 17-23 (2015).

11. Faridah Virgianti Nur. pengaruh keperawataan spiritual emotional freedom technique (seft) islami terhadap tekanan darah penderita hipertensi usia 45-59 tahun di rsud dr. soegiri lamongan. surya 2, (2012).

12. Teti dan Subiayanto. EMOTIONAL FREEDOM TECHNIQUES DAPAT PENURUNAN TEKANAN DARAH. Media Ilmu Kesehata 2, (2013).

13. Thayib, S. . Preview Spiritual Emotional Freedom Technique. (Institute:LoGOS, 2010).

14. Dawson Church, PhD, ${ }^{*}$ Garret Yount, PhD, $P$ and Audrey J. Brooks, P. The Effect of Emotional Freedom Techniques on Stress Biochemistry. J. Nerv. Ment. Dis. 200, 1-6 (2012).

15. Ahmad Faiz Zainuddin. SEFT Spiritual Emotional Freedom Technique seputar aplikasi Praktis untuk Penyembuhan. (2010).

16. Sunardi, Purwanto, E. \& Sakinah, T. EFEKTIFITAS TERAPI SEFT DALAM MENURUNKAN HIPERTENSI ( The Effect of SEFT Therapy to Decrease Hipertension ). J. Ners dan Kebidanan 1, 97-102 (2014). 